быль предприятий и налогом на добавленную стоимость операциий по переводу долга.

Ключевые слова: судебно-экономическая экспертиза, перевод долга, бухгалтерский учет, налоговый учет.

\title{
PECULIARITIES OF FINANCIAL AND TAX ACCOUNTING OF TRANSACTIONS ON DEBT CONVERSION
}

\section{Poroshin D. Yu., Semenova N. Yu.}

The article deals with peculiarities of conducting forensic economic studies connected with collecting income tax and value added tax as well as the order for recording debt conversion in financial accounting. It discusses methods that are used while conducting the studies, lists the relevant articles of normative acts that regulate the order of recording debt conversion transactions in financial accounting. It also considers a number of possible situations for debt conversion transactions, the order of recording them in financial accounting and tax consequences of these transactions. Having analyzed the requirements of the tax legislation, the article claims that debt conversion transactions constitute an object exempt of income tax and vale added tax because: such transactions cannot be classified as obtaining income and do not constitute trade in debt obligations; the transfer of credit debt of one debtor to another is still a liability and not a commodity (work or service); such transactions do not conform with any definition of transactions for the supply of goods, services or factoring.

Keywords: forensic economic examination, debt conversion, financial accounting, tax accounting.

П. О. Івахненко, судовий експерт Харківського НДІСЕ

\section{ПРОБЛЕМНІ АСПЕКТИ ЩОДО ВИРІШЕННЯ ПИТАНЬ ПРИ ПРОВЕДЕННІ СУДОВИХ ЕКОНОМІЧНИХ ЕКСПЕРТИЗ ДОКУМЕНТІВ ФІНАНСОВО-КРЕДИТНИХ ОПЕРАЦІЙ}

Виходячи з експертної практики, розглянуто основні питання, що ставляться на вирішення експертизи документів фінансово-кредитних операцій. Наведено пропозииї щодо змін у науково-методичних рекомендаціях з питань підготовки та призначення судових експертиз і експертних досліджень.

Ключові слова: фінансово-кредитні операції, кредитування, сукупна вартість кредиту, реальна відсоткова ставка, змінювана відсоткова ставка, вартість кредитних ресурсів.

Зважаючи на значне збільшення кількості призначених експертиз, пов'язаних із дослідженням документів фінансово-кредитних операцій, що викликане великим обсягом виданих кредитів на початку 2000-х рр. і по-

(C) Івахненко П. О., 2015 
дальшими кризовими явищами в економіці України, які призвели до погіршення платоспроможності більшості позичальників, зміст експертних завдань постійно розширюється.

Так, підсумовуючи експертну практику проведення експертиз за останні два роки, слід зазначити, що поряд із основними завданнями експертизи фінансово-кредитних операцій, визначеними Науково-методичними рекомендаціями $з$ питань підготовки та призначення судових експертиз та експертних досліджень ${ }^{1}$, на вирішення експертів усе частіше ставляться питання, викликані змінами законодавства у сфері кредитування та банківського нагляду. Серед найбільш поширених питань (завдань) із дослідження кредитних операцій, які ставилися на вирішення експертів за останні роки, можна виділити такі:

- щодо документального підтвердження відповідності умовам договору розрахунків заборгованості, проведених сторонами в цивільній або господарській справі;

— визначення документальної обгрунтованості оформлення та відображення в обліку операцій із видачі, використання й погашення кредитів;

— визначення заборгованості позичальника за кредитним договором перед кредитором;

— визначення документальної обгрунтованості оформлення банківських операцій з відкриття рахунків, руху грошових коштів за кредитами в іноземній валюті;

— пов'язані з відповідністю графіка погашення кредитної заборгованості умовам кредитного договору;

— щодо розрахунку реальної процентної ставки та сукупної вартості кредиту за кредитним договором;

— пов'язані з визначенням і застосуванням плаваючих відсоткових ставок;

— щодо відповідності нарахування процентів за користування кредитом внутрішнім нормативним документам банку;

- пов'язані $з$ документальним обгрунтуванням операцій купівлі-продажу іноземної валюти на Міжбанківській валютній біржі України;

— щодо цільового використання кредитних коштів тощо.

Постійно збільшується кількість досліджень, які передбачають визначення сукупної вартості кредиту, реальної відсоткової ставки, правильності розрахунку періодичних платежів у графіку погашення кредитної заборгованості та інших показників, що надають інформацію про вартість кредитних ресурсів для позичальника. Основною причиною суттєвого збільшення подібних питань, які ставляться на вирішення експертизи фінансово-кредитних операцій, є насамперед унесення змін до Закону Украї-

\footnotetext{
1 Див.: Про затвердження Інструкції про призначення та проведення судових експертиз та експертних досліджень та Науково-методичних рекомендацій з питань підготовки та призначення судових експертиз та експертних досліджень : наказ М-ва юстиції України від 8 жовт. 1998 р. № 53/5 [Електронний ресурс]. — Режим доступу : http://zakon4.rada.gov.ua/laws/show/z0705-98.
} 


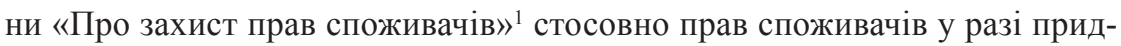
бання ними продукції в кредит і уведення в дію Правил надання банками України інформації споживачу про умови кредитування та сукупну вартість кредиту ${ }^{2}$. Затверджені Національним банком України правила регулюють порядок надання банками споживачу повної, необхідної, доступної, достовірної та своєчасної інформації про сукупну вартість споживчого кредиту (кредиту на поточні потреби, кредиту в інвестиційну діяльність, іпотечного кредиту) з урахуванням процентної ставки за ним, вартості всіх супутніх послуг, а також інших фінансових зобов'язань споживача, які пов'язані з отриманням, обслуговуванням і погашенням кредиту (у тому числі, наданого у формі кредитної лінії, овердрафту за картковим рахунком тощо) і мають бути оплачені споживачем згідно з вимогами законодавства України та/або кредитного договору. Основними завданнями, які вирішує експерт при проведенні досліджень, пов'язаних із сукупною вартістю кредиту, є:

- визначення відповідності розміру сукупної вартості кредиту (у вигляді абсолютного значення подорожчання кредиту (у грошовому вираженні) та реальної процентної ставки (у процентах річних), зазначеного в кредитному договорі або додатках до нього, умовам укладеного між сторонами договору;

- визначення відповідності фактичного розміру сукупної вартості кредиту, розміру цього показника, зазначеного в кредитному договорі (або додатках до нього);

- розрахунок реальної відсоткової ставки відповідно до умов кредитного договору та фактично сплачених позичальником платежів;

- визначення відповідності показника реальної відсоткової ставки розміру відсоткової ставки, зазначеної в кредитному договорі;

- інші питання, пов'язані з розрахунками вартості кредитних ресурсів для позичальника.

У той самий час Науково-методичні рекомендації з питань підготовки та призначення судових експертиз та експертних досліджень не містять подібних завдань серед основних завдань експертизи документів фінансовокредитних операцій і не наводять орієнтовного переліку вирішуваних питань за цими дослідженнями. У зв'язку з цим при призначенні судової економічної експертизи або експертного економічного дослідження дуже часто на вирішення експерта ставляться питання, які передбачають проведення ревізійних дій або потребують надання правової оцінки умов кредитного договору, що не належить до компетенції експертів-економістів.

1 Див.: Про захист прав споживачів : Закон України від 12 трав. 1991 р. № 1023XII [Електронний ресурс]. — Режим доступу : http://zakon3.rada.gov.ua/laws/ show/1023-12.

2 Див.: Про затвердження Правил надання банками України інформації споживачу про умови кредитування та сукупну вартість кредиту : постанова Правління Нац. банку України від 10 трав. 2007 р. № 168 [Електронний ресурс]. - Режим доступу : http://zakon2.rada.gov.ua/laws/show/z0541-07. 
Ще одним напрямом досліджень документів фінансово-кредитних операцій, котрий має тенденцію до збільшення кількості призначених експертиз, $€$ вирішення питань стосовно методів обрахування, відповідності умовам кредитного договору та правильності застосування змінюваної (плаваючої) відсоткової ставки. Чинним законодавством України визначено, що процентна ставка за кредитом може бути фіксованою або змінюваною. Тип процентної ставки визначається договором. Застосування змінюваної (плаваючої) відсоткової ставки в кредитному договорі являє собою схему нарахування відсотків за користування кредитними коштами, за якої розмір річної процентної ставка не фіксується на весь час дії договору, а може змінюватися через певні проміжки часу. Змінювана (плаваюча) процентна ставка, як правило, розраховується за формулою

$$
I_{f}=C+F,
$$

де $I_{f}$ - змінювана відсоткова ставка; $C$ - фіксована частина; $F$ - змінювана частина.

Змінювану частину плаваючої процентної ставки найчастіше становить показник вартості кредитних ресурсів, тобто вартість, за якою банк залучає ресурси. До прийняття Закону України «Про внесення змін до деяких законодавчих актів України щодо заборони банкам змінювати умови договору банківського вкладу та кредитного договору в односторонньому порядку» ${ }^{1}$ в банківській практиці при формуванні змінюваної відсоткової ставки застосовувались як світові індикатори, такі як Libor (Лондонська міжбанківська ставка пропозиціï), EURIBOR (Свропейська міжбанківська ставка пропозиції), так і індекси вартості ресурсів на ринку України (наприклад, UIRDR), i внутрішні показники, що розраховувались і встановлювалися внутрішніми процедурами банку (наприклад, FIDR). Прийнятим законом унесено зміни до Цивільного кодексу України, якими встановлений порядок розрахунку та використання змінюваної процентної ставки. У п. 4 ст. 1056-1 ЦКУ зазначено, що в кредитному договорі встановлюється порядок розрахунку змінюваної процентної ставки із застосуванням погодженого сторонами індексу. Порядок розрахунку змінюваної процентної ставки повинен дозволяти точно визначити розмір процентної ставки за кредитом на будь-який момент часу протягом строку дії кредитного договору. Кредитор не має права змінювати встановлений кредитним договором порядок розрахунку змінюваної процентної ставки без згоди позичальника.

Також у ст. 1056-1 (п. 5) ЦКУ встановлюються чіткі критерії для індексу, що застосовується при формуванні змінюваної відсоткової ставки, а саме індекс, що використовується у формулі визначення змінюваної процентної ставки, повинен відповідати таким вимогам:

Див.: Про внесення змін до деяких законодавчих актів України щодо заборони банкам змінювати умови договору банківського вкладу та кредитного договору в односторонньому порядку : Закон України від 12 груд. 2008 р. № 661-VI [Електронний ресурс]. - Режим доступу : http://zakon1.rada.gov.ua/laws/show/661-17. 
1) поточне значення індексу повинно періодично, але не рідше одного разу на місяць, публікуватися в засобах масової інформації або оприлюднюватися через інші загальнодоступні регулярні джерела інформації. Кредитний договір повинен містити посилання на джерело інформації про відповідний індекс;

2) індекс повинен грунтуватися на об'єктивних індикаторах фінансової сфери, що дозволяють визначити ринкову вартість кредитних ресурсів;

3) значення індексу повинно встановлюватися незалежною установою з визнаною діловою репутацією на ринку фінансових послуг.

Отже, питання, пов'язані з використанням банками в кредитних договорах змінюваної відсоткової ставки, зважаючи на значний обсяг наданих банками кредитів за подібною схемою у 2005-2008 рр. та подальше різке погіршення якості обслуговування кредитної заборгованості, протягом найближчих років будуть усе частіше ставитися на вирішення експертів. При вирішенні подібних питань слід чітко розуміти визначений законодавством порядок застосування змінюваної відсоткової ставки, який існував на момент укладання кредитного договору, а також не виходити за межі компетенції експерта.

Таким чином, постійно зростаюча кількість призначених експертиз, пов'язаних із дослідженням документів фінансово-кредитних операцій, та розширення переліку завдань і питань, які ставляться на вирішення експерта, потребує внесення відповідних змін до Науково-методичних рекомендацій з питань підготовки та призначення судових експертиз та експертних досліджень, а також суттєвого оновлення методичної бази цього напряму досліджень.

\section{ПРОБЛЕМНЫЕ АСПЕКТЫ, КАСАЮЩИЕСЯ РЕШЕНИЯ ВОПРОСОВ ПРИ ПРОВЕДЕНИИ СУДЕБНЫХ ЭКОНОМИЧЕСКИХ ЭКСПЕРТИЗ ДОКУМЕНТОВ ФИНАНСОВО-КРЕДИТНЫХ ОПЕРАЦИЙ}

\section{Ивахненко П. А.}

Исходя из экспертной практики, рассмотрены основные вопросы, которые ставятся на разрешение экспертизы документов финансово-кредитных операций. Приведены предложения, касающиеся изменений в научно-методических рекомендачиях по вопросам подготовки и назначения судебных экспертиз и экспертных исследований.

Ключевые слова: финансово-кредитные операции, кредитование, совокупная стоимость кредита, реальная процентная ставка, изменяемая процентная ставка, стоимость кредитных ресурсов.

\section{PROMBLEATIC ASPECTS OF SOLVING QUESTIONS WHILE CONDUCTING ECONOMIC EXAMINATIONS OF DOCUMENTS ON FINANCIAL AND CREDIT TRANSACTIONS}

\section{Ivakhnenko P. $O$.}

Based on expert practice, the article analyzes main questions that experts are asked to solve when forensic economic examinations are commissioned in order to study documents on financial and credit transactions. The article provides 
a detailed consideration of problems that are connected with determining the total cost of the credit and calculation of the real interest rate for the use of credit resources, as well as the methods to calculate and use the floating interest rate when the credit agreement is concluded. It analyzes the most important tasks that experts solve in the course of the studies on the abovementioned questions. The article provides normative acts that regulate the order for disclosing information on the total cost of credit resources when credit agreements are concluded, the order for the formation of the floating interest rate. It considers problematic aspects of conducting examinations of documents on financial and credit transactions and offers proposals on amending and updating the array of methods in this area of research.

Keywords: financial and credit transactions, crediting, total cost of the credit, real interest rate, floating interest rate, cost of credit resources. перт Дніпропетровського НДІСЕ

\section{ПРОВЕДЕННЯ ЕКОНОМІЧНИХ ДОСЛІДЖЕНЬ СТОСОВНО ОПОДАТКУВАННЯ СІЛЬСЬКОГОСПОДАРСЬКИХ ПІДПРИЕМСТВ}

Розглянуто зміни в нормативно-правових актах України щооо оподаткування сільськогосподарських підприємств, які перебувають на спеціальному режимі оподаткування. 3 'ясовано їх вплив на проведення відповідних економічних експертиз.

Ключові слова: сільськогосподарське підприємство, оподаткування, фіксований сільськогосподарський податок, Податковий кодекс Украӥни.

Із прийняттям Податкового кодексу України відбувся ряд змін стосовно принципів нарахування податків і подання податкової звітності, що має безпосередній вплив на діяльність сільськогосподарських підприємств. Також збільшилась кількість економічних експертиз, пов'язаних із дослідженнями спеціального режиму оподаткування сільськогосподарських підприємств.

На сьогодні відсутня методика 3 проведення досліджень щодо оподаткування податком на додану вартість та порядок застосування спеціального режиму оподаткування сільськогосподарських підприємств. Постійна зміна законодавства ускладнює дослідження за цим напрямком. Так, до початку 2011 р., тобто до прийняття Податкового кодексу України, експерти при дослідженні керувалися законами України «Про фіксований сільськогосподарський податок» від 17 грудня 1998 р. № 320-XIV, «Про податок на додану вартість» від 3 квітня 1997 р. № 168/97-ВР та «Про оподаткування прибутку підприємств» від 22 травня 1997 р. № 283/97-ВР.

У Законі України «Про фіксований сільськогосподарський податок» (зі змінами та доповненнями) зазначено, що товарна сільськогосподарська про- 